\title{
MAKNA DIRI WANITA KARIR SEBAGAI PENYINTAS COVID-19 DI KARAWANG
}

\section{SELF MEANING OF A CAREER WOMAN AS A SURVIVOR OF COVID 19 IN KARAWANG}

\author{
Ade Rinta Aprilianti ${ }^{{ }^{*}}$, Wahyu Utamidewi ${ }^{2}$, Rastri Kusumaningrum. \\ ${ }^{123}$ Program Studi Ilmu Komunikasi, Fakultas Ilmu Sosial dan Ilmu Politik, Universitas Singaperbangsa \\ Karawang
}

*Korespondensi: Ade Rinta Aprilianti Email: ade.rinta17018@student.unsika.com

(Diterima oleh Dewan Redaksi: 17-09-2021)

(Dipublikasikan oleh Dewan Redaksi: 15-10-2021)

\begin{abstract}
Almost all countries in the world have experienced the Covid 19 pandemic which affects almost all aspects of human life. Covid 19 as a new disease that is rapidly transmitted from human to human. In addition, with a lot of information through social media and other platforms, it is not realized that this creates a stigma for people who have been infected with Covid 19, or commonly known as Covid 19 survivors. This study aims to determine the meaning of self from the communication experiences experienced by career women who have survived Covid 19. This study took the subject of career women who survived Covid 19 in Karawang. This research took the subject of career women who were Covid 19 survivors in Karawang. The research method uses a qualitative method with a phenomenological approach aimed at looking at the social phenomena experienced by a career woman who has survived Covid 19. Informants were selected through snowball sampling technique. This study uses the social construction of reality theory. The technique of determining the informants used the snowball sampling technique. The data analysis technique uses data reduction, data presentation and conclusion drawing. Key informants in this study had the initials NT and MH, while the supporting informants were informants with the initials $\mathrm{SO}, \mathrm{EP}$, and $\mathrm{MH}$. The primary data in this study is data that the researchers obtained directly from the main informants, namely the five career women who survived Covid 19 in Karawang. While secondary data in this study is data that researchers get from various kinds of references that have existed before such as journals, theses and books. The data collection technique in this research is in-depth interviews. The results showed that career women who survived Covid 19 interpreted their work as female workers, namely as a profession, ideals, livelihood, motivation and also selfactualization. Career women who have survived Covid 19 interpret themselves as Covid 19 survivors as learning, experience and also reminders of themselves and their families to be more healthy in the midst of the Covid 19 pandemic.
\end{abstract}

Keywords: Self-Meaning; Career Woman; Covid 19 Survivor.

\begin{abstract}
ABSTRAK
Hampir seluruh negara di dunia mengalami pandemi Covid 19 yang mempengaruhi hampir di segala aspek kehidupan manusia. Covid 19 menjadi penyakit baru yang cepat menular dari manusia ke manusia lainnya. Selain itu dengan banyaknya informasi melalui media sosial dan juga platform lainnya, tidak disadari hal ini menimbulkan stigma bagi orang-orang yang pernah terinfeksi Covid 19, atau yang biasa di sebut penyintas Covid 19. Penelitian ini bertujuan untuk mengetahui makna diri dari pengalaman komunikasi yang dialami wanita karir penyintas Covid 19. Penelitian ini mengambil subjek wanita karir penyintas Covid 19 di Karawang. Metode penelitian menggunakan metode kualitatif dengan pendekatan fenomenologi bertujuan untuk melihat fenomena sosial yang dialami oleh seorang wanita karir penyintas Covid 19. Informan dipilih melalui teknik sampling snowball. Penelitian ini menggunakan teori konstruksi sosial atas realitas. Teknik penentuan informan menggunakan teknik sampling snowball. Teknik analisis
\end{abstract}


data menggunakan reduksi data, penyajian data dan penarikan kesimpulan. Key informan pada penelitian ini berinisial NT dan MH sedangkan informan pendukung adalah informan yang berinisial SO, EP, dan MH. Data primer pada penelitian ini adalah data yang peneliti peroleh secara langsung dari informan utama yaitu kelima orang wanita karir penyintas Covid 19 di Karawang. Sedangkan data sekunder pada penelitian ini adalah data yang peneliti dapatkan dari berbagai macam referensi yang telah ada sebelumnya seperti jurnal, skripsi serta buku. Teknik pengumpulan data pada penelitian ini merupakan wawancara mendalam. Hasil penelitian menunjukkan bahwa wanita karir penyintas Covid 19 memaknai pekerjaannya sebagai pekerja wanita yaitu sebagai profesi, cita-cita, mata pencaharian, motivasi dan juga aktualisasi diri. Wanita karir penyintas Covid 19 memaknai dirinya sebagai penyintas Covid 19 adalah sebagai pembelajaran, pengalaman dan juga pengingat diri dan keluarga agar lebih menjaga kesehatan ditengah pandemi Covid 19 ini.

Kata Kunci: Makna Diri; Wanita Karir; Penyintas Covid 19. 


\section{PENDAHULUAN}

Pada 2020 lalu, seluruh dunia dikejutkan dengan peristiwa infeksi berat yang penyebabnya belum diketahui. Kejadian tersebut bermula di Kota Wuhan Provinsi Hubei, China (Yuliana, 2020). Awalnya virus ini diduga karena paparan pasar makanan laut hewan yang banyak menjual berbagai jenis hewan. Covid 19 ini juga menyebar sangat cepat di dalam negeri Cina (Dong et al., 2020).

Ancaman pandemi Covid 19 ini terus membesar ketika bermacam permasalahan menunjukkan penularan antar manusia pada dokter serta petugas kedokteran yang merawat pengidap Covid 19 tanpa ada riwayat berpergian ke pasar yang sudah ditutup (Handayani et al., 2020). Penularan langsung antar manusia ini menimbulkan kenaikan jumlah permasalahan yang luar biasa sampai pada akhir Januari 2020 didapatkan kenaikan 2000 permasalahan terkonfirmasi dalam 24 jam (Handayani et al., 2020).

Dampak interaksi komunikasi dapat signifikan dilihat dari sisi penyintas Covid 19. Dilansir dari (Rahmadi, 2020) para penyintas Covid 19 ini juga berjuang menyembuhkan diri dari stigma masyarakat yang masih kurang informasi tentang Covid 19. Stigma yang ditimbulkan memiliki pandangan penyintas Covid 19 merupakan seseorang yang harus dijauhi dan menimbulkan ketidaknyamanan di lingkungan sekitar. Irmansyah selaku Ketua Jaringan Rehabilitasi Psikologi Indonesia (JRPI) juga mengungkapkan bahwa munculnya stigma negatif dari masyarakat akan turut mempengaruhi proses penyembuhan dari penderita atau pasien. Terdapat beberapa macam dampak perilaku dan juga komunikasi yang dilakukan oleh seorang penyintas virus ini ketika dirinya didiagnosis positif Covid 19. Makna diri pada seorang individu dapat dipengaruhi oleh pengalaman dan pengetahuan individu dan merupakan elemen penting dalam membentuk makna diri sehingga tiap individu memiliki makna diri akan sesuatu hal yang berbeda-beda satu sama lain. Kemampuan orang untuk merespon dirinya sebagai objek memungkinkan mereka berkomunikasi pada dirinya melalui penggunaan simbol. Seseorang melakukan interpretasi terhadap dunia di sekitarnya dan meresponnya berdasarkan interpretasi yang dilakukannya (Samani \& Hariyanto, 2012). Rumusan masalah penelitian ini yaitu bagaimana makna diri dari pengalaman komunikasi yang dialami wanita karir penyintas Covid 19?

\section{MATERI DAN METODE}

\section{Materi}

\section{Teori Konstruksi Sosial atas Realitas}

Teori ini memiliki arti suatu proses sosial dengan perilaku dan interaksi dimana seseorang atau kelompok, membuat suatu realita yang dialami dan dimiliki bersama dengan subyektif. Teori konstruksi sosial atas realitas berlandaskan pada paradigma konstuktvis dimana mengamati realita sosial sebagai kontruksi sosial yang ditimbulkan oleh manusia. Manusia menjadi penetap di kehidupan sosial yang dikonstruksikan berlandaskan keinginannya, dan pada beberapa hal mempunyai keleluasan berperilaku lewat batas kontrol struktur dan pranata sosial. Pada proses sosial, seseorang dilihat selaku pembentuk realitas sosial dimana cenderung bebas didalam kehidupan sosialnya (Kuswarno 2009 dalam Wiratama, 2018).

Untuk mendalami teori kontruksi social Peter Berger ini, terdapat tiga momen penting yang harus diketahui. Ketiga momen itu antara lain yaitu eksternalisasi, objektivasi, dan internalisasi dimana menurut Berger mempunyai keterkaitan dasar serta diketahui selaku suatu proses yang saling berdialektika. Ketiga momen saling berkaitan dengan sebuah karakterisasi yang esensial 
terhadap kehidupan sosial. Dengan eksternalisasi, masyarakat adalah produk manusia, dengan objektivasi masyarakat menjadi realitas sui generis, unik dan dengan internalisasi manusia adalah produk masyarakat (Berger, 1994 Perwira 2019).

Teori konstruksi sosial mempunyai asumsi dasar yang dipelopori oleh Berger dan Luckmann yaitu adanya keterkaitan dimana terus berlangsung diantara makna dan maknanya di dunia ini (dan) manusia memiliki akal sehat mengenai realitas (mereka).

Asusmsi tersebut disempurnakan agar menggambarkan proses realitas diciptakan dengan sosial. Pada komunikasi, asusmsi pada teori ini merupakan manusia mengalami pengalaman melalui cara menciptakan sesuatu model dunia sosial serta bagaimana dia bertindak. Pada hakikatnya, teori ini menimbulkan asumsi ontologis dimana adalah hakekat eksistensi manusia.

\section{Komunikasi Antarpribadi}

Komunikasi ini dapat disebut sebagai komunikasi interpersonal yaitu komunikasi yang dilaksanakan dari seseorang untuk bertukar pikiran satu sama lain. Dalam arti lain komunikasi antarpribadi merupakan salah satu topik komunikasi yang setiap orang menyampaikan pikiran, pendapat, emosi, dan juga informasi lainnya secara face to face atau bertatap muka dengan individu lainnya. Komunikasi antarpribadi ini dilakukan bisa bentuk verbal maupun nonverbal. Komunikasi antarpribadi ini bukan membahas mengenai apa yang dikatakan dan apa yang diterima saja tetapi juga membahas mengenai bagaimana bahasa tubuh digunakan, hal itu dikatakan, dan juga ekspresi wajar yang diberikan (Novianti, 2017).

\section{Kerangka Pemikiran}

Penelitian ini berjudul "Wanita Karir Sebagai Penyintas Covid 19" yang mengkaji mengenai makna diri yang dimaknai oleh para wanita karir sekaligus penyintas
Covid 19. Di masa pandemi Covid 19 ini banyak perubahan yang terjadi seperti pada kehidupan sosial. Diterapkannya social distancing juga menjadi salah satu faktor perubahan pada kehidupan sosial. Peneliti ingin meneliti lebih jauh lagi bagaimana wanita karir memaknai dirinya sebagai penyintas Covid 19. Dengan menggunakan pengalaman komunikasi yang dimiliki para informan, dapat memicu objektivasi interpretasi terhadap pengalaman tersebut dan menimbulkan makna diri yang baru.

\section{Gambar 1 Diagram Kerangka Pemikiran}

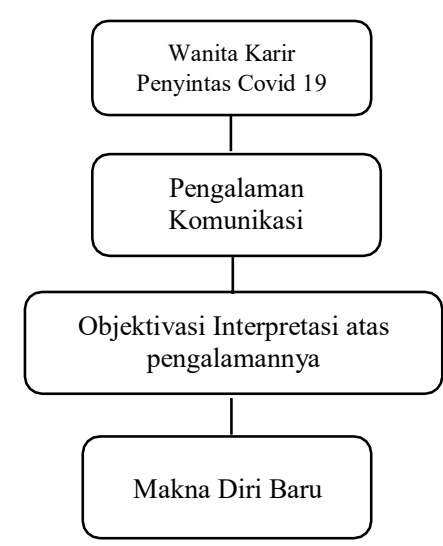

\section{Metode}

Metode dalam penelitian ini memakai metode penelitian kulitatif serta pendekatan fenomenologi. Peneltian kuliatatif merupakan pendekatan yang menggambarkan, menerangkan dan juga mengeksplorasi peristiwa atau objek sosial yang tidak bisa dijelaskan, dan tidak dapat di jumlahkan secara numberik atau hitungan (Yati Afiyanti, 2014).

Pendekatan fenomenologi ini mempunyai tujuan untuk bisa mengetahui fenomena oleh seseorang yang menghadapinya secara langsung atau berhubungan pada sifat - sifat alami makna yang tersirat dan pengalaman manusia (Kuswarno, 2009 dalam Putri W, 2018).

Tujuan dari fenomenologi yaitu untuk mengetahui bagaimana peristiwa dialami secara sadar, pikiran serta pada action atau tindakan, misalnya bagaimana peristiwa diterima atau bernilai dengan estetis. Fenomenologi berusaha 
menemukan pembahasan bagaimana individu mengkonstruksi makna dan konsep-konsep penting pada kerangka intersubyektivitas. Intersubyektif sebab pemahaman individu perihal dunia diciptakan oleh keterkaitan individu dengan individu lainnya. Meskipun makna yang individu timbulkan dapat dicari dalam tindakan, karya dan aktivitas yang kita lakukan, tetap saja ada peran orang lain didalamnya (Kuswarno, 2009 dalam Putri $W, 2018)$. Subjek penelitian pada penelitian ini yakni wanita karir penyintas Covid 19 yang sudah berkeluarga di Kab. Karawang.

Dalam penelitian ini peneliti memakai teknik Teknik analisis data menggunakan reduksi data, penyajian data dan penarikan kesimpulan. Data primer pada penelitian ini adalah data yang peneliti peroleh secara langsung dari wawancara mendalam. Wawancara dan dilakukan secara online karena adanya pandemi Covid 19 di Karawang saat ini. Wawancara online dilakukan melalui Zoom dan juga Whatsapp Call. Wawancara dilakukan selama 30-60 menit tiap informan. Dan merupakan wawancara yang semi tersturktur agar dapat membangun komunikasi yang mendalam pada informan. Sedangkan data sekunder pada penelitian ini adalah data yang peneliti dapatkan dari berbagai macam referensi yang telah ada sebelumnya seperti jurnal, skripsi serta buku. Jurnal yang terdiri dari berbagai macam sumber seperti Jurnal ekomunikasi, Jurnal Respirologi Indonesia, Jurnal Perspektif, Jurnal Pendidikan Islam, Jurnal JOM Fisip, Jurnal Gawat Darurat dan lainnya.

Setelah hasil diperoleh, peneliti selanjutnya akan menggambarkan dan mendeskripsikan hasil penelitian tersebut melalui in depth interview pada informan. Penelitian ini menggunakan teknik sampling snowball untuk penentuan informan. Teknik sampling snowball adalah suatu cara atau metode yang berguna untuk mengidentifikasi, meilih dan mengambil sample pada suatu jaringan atau ikatan atau dengan kata lain teknik ini merupakan jenis metode sampling dimana sampel diperoleh dengan cara merambat dari satu informan ke informan lainnya (Neuman, 2015). Teknik sampling snowball ini digunakan karena untuk memudahkan peneliti untuk mendapatkan informan yang sesuai dengan karakteristik pada penelitian ini. Karakteristik informan pada penelitian ini adalah wanita karir yang menjadi penyintas Covid 19 yang memiliki keluarga dan usia pernikahan lebih dari setahun, berusia produktif yaitu 25 sampai 49 tahun serta berdomisili di Kabupaten Karawang. Teknik ini digunakan karena informan yang terdapat dalam penelitian ini pada dasarnya merupakan orang-orang yang saling terikat satu sama lain. Dari tiap informan memiliki hubungan tertentu dengan informan lainnya seperti teman, rekan kerja, saudara, tetangga dan lain-lain. Penelitian ini berlangsung di Karawang. Dan dilaksanakan pada bulan April.

\section{HASIL DAN PEMBAHASAN}

Fenomena sosial pada dasarnya adalah makna yang berhubungan dengan komunikasi. Makna selaku konsep komunikasi mencakup luas dari pemahaman atau penafsiran seseorang saja, namun senantiasa mencakup berbagai pemahaman.

Bermacam perubahan dalam persepsi diri wanita karir penyintas Covid 19 dan persepsi seseorang atas realitas menimbulkan perubahan pada waktu yang sama pada perilaku, serta hal tersebut menyebabkan keadaan psikologis tertentu terhadap wanita karir penyintas Covid 19 sehingga memiliki kamampuan untuk mereorganisasi bidang persepsinya, termasuk bagaimana indovidu memandang diri mereka sendiri.

Hasil penelitian ini mencakup dua pokok permasalahan yaitu wanita karir memaknai peran dirinya sebagai wanita karir sekaligus ibu rumah tangga, serta wanita karir memaknai dirinya sebagai penyintas Covid 19. 
Dengan pengalaman yang dialami oleh informan memunculkan pertanyaan yang merujuk pada bagaimana makna diri wanita karir penyintas Covid 19 di Karawang. Setiap orang memiliki pengetahuan dan interpretasi akan suatu hal yang berbeda-beda. Pengalaman ini dapat membentuk suatu makna pada individu itu sendiri. Hal ini lah yg disebut sebagai makna perorangan, tetapi jika setiap makna itu mempunyai sifat perorangan, tentu tidak terjadi komunikasi dengan orang lain (Indriyani \& Yusuf, 2020).

Para ahli komunikasi menggunakan sebutan makna saat para ahli menguraikan penjelasan komunikasi. Menurut Stewart L. Tubbs dan Sylvia Moss (L. Tubbs \& Moss, 2006 dalam Wono, 2019) menyatakan bahwa komunikasi merupakan proses pembentukkan makna diantara dua individu atau kelompok. Serta Judy C. Person dan Paul E. Nelson mengatakan "Komunikasi merupakan proses menginterpretasikan dan berbagi makna". Adanya berbagai komponen makna yang diciptakan sebuah kata atau kalimat (Alex Sobur, 2009 dalam Periwira, 2019).

Berdasarkan wawancara yang telah dilakukan kepada lima orang informan, setiap informan mempunyai makna diri yang berbeda satu sama lain. Data yang diambil dari penelitian ini memakai metode wawancara mendalam atau biasa disebut in depth interview yang dilakukan kepada lima informan wanita karir penyintas Covid 19:

Tabel 1 Identifikasi Subjek Penelitian

\begin{tabular}{llll}
\hline Informan & $\begin{array}{l}\text { Jenis } \\
\text { Kelamin }\end{array}$ & Usia & Pekerjaan \\
\hline SO & Perempuan & 47 & $\begin{array}{l}\text { Usaha } \\
\text { bisnis } \\
\text { online }\end{array}$ \\
NT & Perempuan & 29 & Karyawan \\
EP & Perempuan & 30 & Dosen \\
FR & Perempuan & 28 & Bidan \\
MH & Perempuan & 25 & Pegawai \\
\hline
\end{tabular}

Sumber : Hasil wawancara, 2021

Seluruh informan di atas sudah memenuhi karakateristik informan pada penelitan ini, diantaranya wanita karir yang sudah berkeluarga, usia produktif 25 sampai 49 tahun, memiliki usia pernikahan diatas satu tahun, dan berdomisili di Karawang, Jawa Barat.

Dengan data kelima informan yang mempunyai latar belakang pendidikan, ekonomi, lingkungan yang berbeda satu sama lain, terdapat beberapa hasil dari makna diri yang ditimbulkan oleh kelima informan tersebut. Kelima wanita karir sekaligus penyintas Covid tersebut memberikan makna diri yang berbedabeda sesuai dengan pengalaman, dan juga respon atau tanggapan masyarakat sekitar. Berikut tabel yang dapat menggambarkan pemaknaan diri wanita karir sekaligus penyintas Covid 19:

Tabel 2 Makna Diri Wanita Karir Penyintas Covid 19

\begin{tabular}{|c|c|c|c|}
\hline \multirow{2}{*}{ No. } & \multirow{2}{*}{ Informan } & \multicolumn{2}{|c|}{ Makna Diri Wanita Karir Penyintas Covid 19} \\
\hline & & Sebagai Wanita Karir & Sebagai Penyintas Covid 19 \\
\hline 1. & SO & $\begin{array}{l}\text { Seorang ibu yang berusaha } \\
\text { melakukan hobi pada waktu } \\
\text { luang di rumah serta membantu } \\
\text { perekonomian keluarga }\end{array}$ & $\begin{array}{l}\text { Menjadi pembelajaran diri dan } \\
\text { dapat menjadi pengawas } \\
\text { kesehatan dalam keluarga }\end{array}$ \\
\hline 2. & NT & $\begin{array}{l}\text { Seorang ibu yang berusaha } \\
\text { membantu perekonomian } \\
\text { karena kebutuhan keluarga dan } \\
\text { juga pengobatan suami }\end{array}$ & $\begin{array}{l}\text { Menjadi pembelajaran dan } \\
\text { pengalaman untuk lebih menjaga } \\
\text { kesehatan diri dan keluarga }\end{array}$ \\
\hline
\end{tabular}




\begin{tabular}{|c|c|c|c|}
\hline \multirow[b]{2}{*}{ No. } & \multirow[b]{2}{*}{ Informan } & \multicolumn{2}{|c|}{ Makna Diri Wanita Karir Penyintas Covid 19} \\
\hline & & Sebagai Wanita Karir & Sebagai Penyintas Covid 19 \\
\hline 3. & EP & $\begin{array}{l}\text { Seorang ibu yang bercita-cita } \\
\text { sebagai pengajar dan memiliki } \\
\text { posisi yang seimbang dalam } \\
\text { mengurus keluarga }\end{array}$ & $\begin{array}{l}\text { Makna pembelajaran diri dan } \\
\text { keluarga, serta menerima dan } \\
\text { menjalaninya dengan ikhlas }\end{array}$ \\
\hline 4. & FR & $\begin{array}{l}\text { Seorang istri yang menyukai } \\
\text { profesinya sebagai bidan dan } \\
\text { tenaga kesehatan Covid } 19\end{array}$ & $\begin{array}{l}\text { Menjadi pengingat diri dan } \\
\text { keluarga untuk lebih menjaga } \\
\text { kesehatan dan juga kebersihan }\end{array}$ \\
\hline 5. & $\mathrm{MH}$ & $\begin{array}{l}\text { Seorang istri yang ingin memiliki } \\
\text { penghasilan sendiri yang tidak } \\
\text { bergantung pada suami }\end{array}$ & $\begin{array}{l}\text { Menjadi pengalaman untuk lebih } \\
\text { menjaga kesehatan dan juga lebih } \\
\text { aware pada Covid } 19\end{array}$ \\
\hline
\end{tabular}

Sumber : Hasil wawancara, 2021

\section{Makna Diri Sebagai Wanita Karir}

Berkaitan dengan pemaknaan wanita karir. Wanita karir adalah peran seorang wanita dimana selain menjadi sosok ibu rumah tangga yang masih aktif bekerja dan berkarir. Dengan kata lain, wanita karir merupakan wanita yang memiliki peran ganda yakni selain menjadi ibu rumah tangga atau istri dalam keluarga, serta menjadi pekerja aktif mengerjakan tugas- tugas diluar urusan kerumah tanggaan (Qomar, 2015).

Sebuah keluarga yang beberapa dari mereka berupaya untuk meringankan beban suami untuk memenuhi kebutuhan keluarga serta melakukan pekerjaan impian atau cita-cita mereka. Penting untuk menganalisis motif apa yang mendasari para wanita karir ini dalam berkarir sehingga dapat diketahui juga makna yang diditimbulkan dalam profesinya. Menurut persepsi fenomenologi oleh Schutz interpretasi yang ditimbulkan oleh seseorang tentang pengalamannya sehingga menimbulkan makna spesifik dan juga pengalaman komunikasi denga lingkungan sekitar pada konteks historis simultan, yaitu masa lampau, masa sekarang serta masa depan (Kuswarno, 2009 dalam Perwira 2019), dimana pada topik tersebut adanya motif yang merangsang seseorang agar bertindak, maka motif berkarir dari para wanita karir ini penting untuk diketahui. Motif tersebut juga menjadi dasar dari pilihan para wanita karir ini untuk berkarir seperti yang sudah dijelaskan pada tabel diatas, untuk para informan dalam penelitian ini berdasarkan terhadap alasan ekonomi, dan juga impian pribadi.

Motif merupakan dorongan yang mengakibatkan seseorang untuk bertindak sesuatu action atau perilaku tertentu agar menggapai tujuan tertentu. R. S. Woodworth dalam Sobur (2003) menyatakan bahwa motif menjadi sebuah motivasi yang bisa mengakibatkan seseorang agar bertindak kegiatan tertentu agar menggapai tujuan tertentu (Perwira, 2019)

Schutz menjelaskan perspektif fenomenologinya bahwa memandang ke depan di masa depan (looking-forward into the future) adalah hal esensial terhadap konsep tindakan (action). Tindakan atau action merupakan tingkah laku didorong agar menggapai tujuan di masa yang sudah ditentukan (determinate). Hal itu memiliki makna setiap individu mempunyai masa lampau (pastness). Maka dari itu, tujuan dari tindakan mempunyai elemen masa yang akan datang (futurity) serta elemen masa lampau (pastness) dimana mendefinisikan tujuan suatu tindakan sosial individu yang kompleks (Kuswarno, 2009 dalam Utamidewi et al, 2017).

Pada masa lampau, kini serta depan, proses persepsi bisa dipakai untuk menggambarkan atau memperjelas makna yang sebenarnya, sehingga bisa 
menimbulkan konsep kepekaan yang implisit. Maka dari itu, dasar tindakan sosial pada inti pemikiran Schutz yakni cara untuk mengartikan action atau tindakan sosial dengan perspektif. Tindakan sosial adalah suatu tindakan yang berdasarkan tingkah laku individu atau pengalaman orang lain, kesadaran dan makna. Seseorang mengkonstruksi makna keluar arah pengalaman dengan proses tipikasi. Keterkaitan diantara makna juga diorganisasikan dengan proses tersebut (stock of knowledge) (Kuswarno, 2009 dalam Utamidewi et al, 2017). Dan untuk menjelaskan seluruh tindakan individu, Schutz mengelempokkanya kedalam dua tahap, diantaranya :

a. Weil Motiv (Because motives)

Motif ini merupakan perilaku yang berpacu pada masa lampau. Yang dimana tindakan atau action yang dilakukan oleh individu mempunyai alasan dari masa lampau saat individu itu bertindak.

b. Um-zu Motiv (In-Order-to-Motiv)

Jenis ini adalah motif yang tertuju kepada tindakan dimasa depan. Dimana tindakan yang dilakukan individu mempunyai tujuan yang telah ditentukan.

Kedua motif tersebut umumnya disebut sebagai sebab atau alasan. Berlandaskan proses wawancara serta observasi kepada lima informan di penelitian ini membuktikan bahwa seluruh motif yang terdapat pada makna diri wanita karir penyintas Covid 19 merujuk pada “motif karena' (in order to motive). Sebab berdasarkan wawancara beberapa informan, motif untuk membantu memenuhi kebutuhan ekonomi rumah tangga adalah motif yang paling dasar serta motif untuk memenuhi impian atau citacita informan juga menjadi motif pada informan dalam penelitian ini.

Gambar 2 Makna Diri Sebagai Wanita

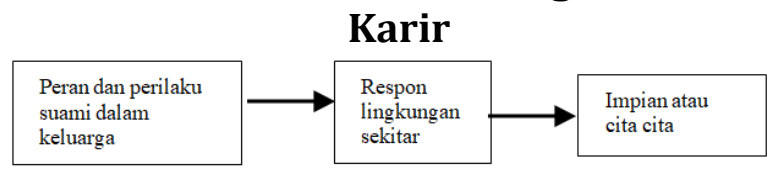

Berdasarkan pemaknaan diatas, dapat dibuat kategorisasi makna diri wanita karir sebagai penyintas Covid 19 sebagaimana yang disajikan dalam tabel 1 . Pada diagram ini, menjelaskan bahwa pengalaman komunikasi keluarga wanita karir dalam menciptakan makna diri sebagai wanita karir sangat memiliki pengaruh. Proses menjalankan interaksi agar dapat mempertahankan keharmonisa dalam keluarga dan saling berbagi konstribusi dalam kebutuhan rumah tangga, menurut para informan komunikasi dalam keluarga menjadi sesuatu yang penting karena keluargalah yang menjadi salah satu alasan yang membuat para informan memilih untuk bekerja. Karena adanya keluarga dipandang menjadi "umat kecil" yang didalamnya mempunyai pemimpin serta anggota yang memiliki hak dan kewajiban dan tugasnya masingmasing. Kelaurga bisa dilihat selaku pranata sosial yang pertama dan utama menjadi modal awal perjalanan hidup, yang lalu di lengkapi dengan tanda- tanda perjalanan yang ditetapkan oleh pranata sosial lainnya dilingkungan sekitar. Keluarga juga memberikan pengaruh besar terhadap seluruh anggotan di dalamnya, karena didalam keluarga terdapat interaksi yang mendasar, intim dan juga bermakna (Majid, 2000 dalam Muhasar 2019). Dalam keluarga mempunyai peran pemimpin yakni seorang ayah yang memiliki peran untuk menafkahi keluarganya. Jika seorang ibu ingin bekerja dan mempunyai penghasilan mandiri itu boleh dengan syarat bisa untuk membagi waktu antara pekerjaan dan mengurus keluarga. Jika wanita karir tidak peduli dengan urusan dan perannya sebagai seorang ibu dan istri dalam keluarga, sulit untuk menciptakan pengalaman komunikasi yang harmonis dalam sebuah keluarga.

Beberapa informan pada penelitian ini memaknai pekerjaan yang sedang dilakukannya adalah sesuatu yang di syukuri karena merupakan salah satu citacitanya. Makna tersebut muncul melalui pengalaman para informan dengan 
subyektif tentang profesi tersebut. Berdasarkan penuturan Evi, sudah menjadi cita-citanya sejak dulu untuk menjadi seorang pengajar. Selain menginginkan penghasilan mandiri dan juga ingin memiliki kedudukan yang sama dalam hal mengurus kebutuhan keluarga.

Sebuah impian dalam setiap individu dapat berbeda-beda, dalam setiap impian merupakan keinginan yang positif, yang dapat memacu individu tersebut untuk meraih sesuatu hal yang indah yaitu cita- cita. Impian adalah motivasi dalam meraih cita-cita karena motivasi merupakan suatu pendorong yang sangat mempengaruhi cita-cita. Serta motivasi ini hanya dapat terbentuk dari dalam diri individu itu sendiri (Hidayat, 2020).

Sama halnya dengan FR, FR merasa membutuhkan pengembangan diri serta potensi. Dan dengan bekerja FR dapat memperluas relasi dan pengalaman.

Berbeda halnya dengan SO, SO menjalankan bisnisnya karena untuk mengisi waktu luang dirumah sekaligus melakukan hobinya yaitu memasak. Sedangkan bagi NT, NT juga merasa memiliki kewajiban untuk membantu memenuhi kebutuhan karena pengobatan rutin yang harus dijalani suami. Pada tiap wanita karir dalam penelitian ini mempunyai makna masing-masing yang berbeda satu dengan lainnya yang bisa dipengaruhi oleh faktor lingkungan sekitar, ekonomi, dan juga latar belakang para informan.

\section{Makna Diri Sebagai Penyintas Covid 19}

Seorang individu memposisikan dirinya dan action (tindakan) individunya pada tatanan sosial dengan makna dari sistem makna pada dirinya sendiri. Seorang individu memutuskan suatu perspektif dari peristiwa serta pengalaman serta tatanan persepsi yang luas, yang terdapat pada sistem makna. Berger menyatakan bahwa sistem makna yang dipakai oleh individu akan memudahkannya untuk mengetahui sifat individu lain, tujuan dari keterlibatan pada aktivitas, signifikan dalam menjadi individu di sekitarnya mengetahui pentingnya peran yang dimiliki pada kelompok (Berger, 1994 dalam Perwira, 2019).

Mulyana menyatakan bahwa makna bukan berasal dari kata melainkan makna itu diberikan oleh seseorang. Kata-kata ini dapat menimbulkan makna yang terdapat pada pemikiran seseorang. Makna yang diberikan oleh seorang individu dapat berbeda bergantung pada waktu dan ruang. Sebuah makna timbul dari keterkaitan khusus antara kata (sebagai simbol verbal) serta individu (Mulyana, 2010 dalam Arriandi 2014).

Makna yang ditimbulkan para informan pada penelitian ini memiliki hasil yang bermacam-macam. Makna ini juga berhubungan dengan latar belakang yang dimiliki informan, pola komunikasi dalam keluarga, dan juga respon dari masyarakat sekitar.

Makna pertama yang ditimbulkan oleh penyintas Covid 19 sekaligus para wanita karir ini membuat para informan pada penelitian ini memiliki rasa tertutup terhadap dunia luar karena adanya stigma di masyarakat sekitar, seperti yang dinyatakan NT, NT mengaku mengalami stigma yang dilakukan tetangga sekitarnya. Bahkan stigma itu juga diterima oleh anak NT yang dinyatakan negatif. Dan bahkan stigma ini masih diterimanya setelah NT dinyatakan negatif. Stigma ini berupa tetangganya yang menjauh saat NT dan keluarga keluar rumah, lebih memilih jalan yang lebih jauh dibandingkan harus lewat rumah NT dan sebagainya. Stigma ini membuat NT dan keluarga menjadi tertutup di lingkungan sekitarnya. "Respon tetangga saat itu ada yg baik ada nada juga yang jadi takut, malah lewat rumah teteh juga pada gak berani. Pas papas an pada tutup hidung padahal itu teteh udah negatif"

Stigma adalah suatu istilah yang mendefinisikan suatu kondisi atau keadaan yang dianggap bernilai negatif. Menurut (Arboleda, 2002 dalam Abdillah, 2019) stigma didefinisikan selaku konstruksi 
sosial dimana simbol memilah aib sosial terdapat pada individu lainnya agar mengevaluasi serta mengidentifikasinya. Pada dasarnya stigma terdapat dalam pikulan penderita. Stigma sosial pada topik kesehatan merupakan keterkaitan negative diantara individu atau kelompok individu lain yang berbagi suatu penyakit serta suatu karakteristik tertentu (WHO, 2020).

Seperti yang dijelaskan oleh Livana, Setiawati, dan Sariti, dampak sosial dari adanya stigma di masyarakat ini salah satunya adalah memotivasi individu agar menutupi penyakit yang ia derita agar dapat menjauhi diskriminasi dari masyarakat sekitarnya. Tidak dipungkiri, sudah banyak kasus dimana terjadi pada pasien penyakit lainnya seperti TBC, HIV, kusta serta yang lainnya menerima stigma negatif dari masyarakat (Setiawati et al, 2020).

Sama halnya dengan $\mathrm{MH}$ yang juga menyembunyikan kabar positif Covid 19 dengan tetangga. Seperti yang dijelaskan (Joharudin et al., 2020) adanya proses interaksi sosial yang menimbulkan sebuah perubahan sosial selalu berkaitan dengan terdapatnya kegiatan komunikasi yang sekaligus sebagai salah satu ruang lingkup kehidupan masyarakat disetiap kondisi dan situasi. Sikap dari lingkungan sekitar juga mempengaruhi interaksi sosial dari masing-masing orang. Dan interaksi sosial yang ditimbulkan dapat memutuskan untuk menjauhi kehidupan sosial dimasyarakat notmal serta menimbulkan rasa menutup diri.

Pembentukan makna diri dari para informan yang dijelaskan diatas merupakan sebuah makna yang dihasilkan melalui konstruksi realitas dari masyarakat dan lingkungan sekitar. Sifat tertutup yang ditimbulkan dari para penyintas Covid 19 ini juga dipengaruhi oleh pemberitaan media di beberapa platform yang menyebabkan ketakutan bagi para penyintas Covid 19. Sama halnya dengan yang dijelaskan oleh informan $\mathrm{MH}$ dan NT yang memutuskan untuk bersikap tertutup karena mereka takut akan menerima stigma negatif dari masyarakat sekitar. Seperti yang dijelaskan Irmansyah Ketua Jaringan Rehabilitas Psikososial Indonesia (JRPI) bahwa adanya stigma negatif dapat berakibat mempengaruhi proses penyembuhan pada pasien. Stigma tercipta dari persepsi, dan persepsi ini muncul dari pengetahuan pada tiap orang dimana mempunyai interpretasi kepada sebuah peristiwa. Irmansyah juga menjelaskan fenomena dimasyarakat Indonesia lebih menyukai berita negatif, kontroversi, kematian dan lainnya (Rahmadi, 2020).

Hal ini menajdi faktor para informan terdorong untuk mengubah makna diri dari interaksosial kepada sikap tertutup dari masyarakat karena mempunyai rasa takut akan mendapatkan stigma negatif dari masyarakat.

\section{Gamber 3 Sikap Tertutup}

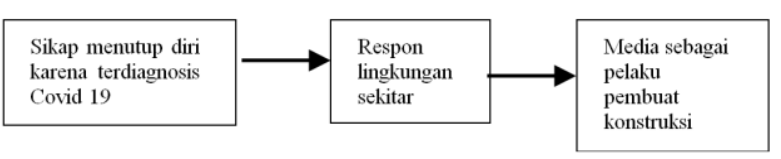

Pada tahap pertama ini, kata "tertutup" memiliki banyak makna dari berbagai persoalan yang terdapat di dalamnya. Pertama, terdapat stigma negatif mengenai Covid 19. Dimana virus Corona termasuk virus yang dapat menular serta dapat menjadi sebuah aib bagi seorang yang terdiagnosis positif Covid 19 dan juga keluarganya. Serta anggapan negatif terhadap terdiagnosis Covid 19 dekat dengan kematian. Stigma negatif itu terjadi karena anggapan Covid 19 belum memiliki obat yang dapat menyembuhkan dan penyakit ini juga memiliki dampak yang besar pada kesehatan manusia. Dengan adanya sikap menutup diri menjadi faktor perubahan budaya yang signifikan. Dilansir dari liputan6.com, dari hasil survey sejumlah responden menyatakan dimana terdapat perubahan pada kehidupan sosial karen adanya pandemic Covid 19. Dimana awalnya warga Indonesia lekat dengan sikap sosial dan gotong royong yang terjadi pada kehidupan sehari-harinya, menjadi terbatas karena adanya penerapan 
kebijakan-kebijakan dari pemerintah agar berhentinya penyebaran Covid 19 ini. Budaya tersebut sangat mempengaruhi terhadap konstruksi yang terjadi pada pandemi Covid 19 ini. Pembentukan budaya juga dipengaruhi oleh kehidupan sosial pada lingkungan tersebut. Peran lingkungan dalam membentuk sebuah makna diri yang ditimbulkan dari perilaku sosial yang dapat dirasakan dalam lingkungan tersebut (Dianawanti, 2020).

Dilansir dari kumparan.com sikap menutup diri ini sudah banyak dialami oleh pasien positif Covid 19. Dr. Retno Asti Werdhani menegaskan bahwa masyarakat untuk tidak memberi label atau stigma negatif terhadap pasien Covid 19. Asti juga menyatakan stigma negatif dapat berakibat buruk bagi pelacakan atau tracing pada pasien Covid 19. Pasien juga akan lebih menutup diri dan enggan terbuka mengenai riwayat perjalanan dan juga orang-orang yang kontak erat dengan pasien (Audita, 2020).

Bahaya akan adanya stigma negatif ini bukan hanya berdampak pada pasien saja, namun dapat berdampak pada orangorang sekitarnya juga. Stigma ini mengakibatkan mereka yang ketakutan untuk mengakui bahwa mereka pernah bertemu dengan pasien Covid 19, serta tidak mau dipantau atau di tracing. Padahal fungsi dari tracer adalah untuk mengidentifikasi serta membantu mereka yang terdiagnosis positif Covid 19, bukan ingin mencari tersangka atau membongkar aib.

Selain itu, faktor munculnya stigma negatif pada masyarakat Indonesia adalah dengan adanya pemberitaan negatif di media. Para informan juga mengungkapkan bahwa media menjadi salah satu alasan mereka bersikap menutup diri dari masyarakat karena adanya pemberitaan negatif yang terus menerus disajikan oleh media. Selain itu, sikap tertutup pada seorang individu mempunyai hubungan dengan kesadaran masyarakat tentang peran media itu sendiri. Banyak pemberitaan di media yang menambahkan atau mengurangi materi berita yang disajikan dengan tujuan untuk mendapatkan empati dari masyarakat.

Menurut Hidayah penyebab

masyarakat mengalami serangan kecemasan karena adanya pemberitaan pada media yang melebih-lebihkan dari situasi yang sebenarnya. Selain itu kecemasan juga dialami masyarakat ketika ada berita mengenai kasus terdiagnosis positif di lingkungan sekitarnya. Berdasarkan uraian tersebut dapat dilihat seberapa besar dampak yang ditimbulkan dari pemberitaan dimedia yang dapat mengakibatkan kontroversi dari masyarakat (Hidayah et al., 2020).

\section{KESIMPULAN DAN IMPLIKASI}

\section{Kesimpulan}

Berlandaskan uraian pada hasil penelitian dan penyajian konsep daj juga teori pada pembahasan, kesimpilan yang di dapat peneliti pada penelitian ini antara lain:

1) Makna diri dari wanita karir di Karawang yaitu memaknai pekerjaan yang sedang digelutinya adalah sesuatu yang disyukuri dan merupakan salah satu impian mereka untuk berprofesi sesuai dengan latar belakang pendidikan dan juga minat masingmasing informan.

2) Makna diri penyintas Covid $19 \mathrm{di}$ Karawang yaitu menutup dirinya dari kehidupan lingkungan sosial karena banyaknya stigma negatif di masyarakat. serta tidak luput dari pengaruh media yang terus menerus menyajikan berita negatif yang membuat para penyintas Covid 19 ini mengalami kecemansan dalam dirinya. Dan juga makna diri yang dibentuk bagi wanita karir penyintas Covid 19 pada penelitian ini berdasarkan pengalaman interaksi dimana dialami para informan di masa sekarang dan juga masa lalu sehingga membentuk konstruksi makna. 


\section{Implikasi Teoritis}

Implikasi teoritis dalam penelitian ini antara lain sebagai berikut :

1) Pengalaman komunikasi dari seorang penyintas Covid 19 dapat berpengaruh pada makna diri yang dihasilkan. Pengalaman komunikasi negatif yang dialami dari para informan sebagian besar datang dari stigma yang ditimbulkan dari masyarakat. Maka dari itu diharapkan agar kedepannya masyarakat tidak lagi melakukan stigma negatif terhadap penyintas Covid 19. Oleh karena itu perlunya membangun komunikasi yang baik terhadap pasien maupun penyintas Covid 19 ini saat ataupun setelah masa karantina. Agar pasien Covid 19 dapat terus memiliki pikiran positif.

2) Dukungan positif dari teman dan juga keluarga terbukti dapat membantu proses pemulihan seorang pasien Covid 19. Maka dari itu perlunya pengertian serta dukungan dari teman, keluarga maupun rekan kerja dari pasien Covid 19, agar para pasien Covid 19 tidak memaknai dirinya maupun penyakit yang dideritanya kepada hal-hal yang negatif, karena seperti yang sudah dijelaskan pada pembahasan bahwa makna merupakan hasil dari proses interaksi dan komunikasi.

\section{Implikasi Praktis}

Hasil penelitian ini dapat digunakan sebagai pengingat untuk masyarakat akan bahayanya Covid 19 serta dampak yang ditimbulkan dari Covid 19 terhadap pengidapnya, yang dimana tidak hanya berdampak pada kesehatan fisik tetapi juga berdampak pada kesehatan mental. Dan diharapkan kedepannya masyarakat.

\section{DAFTAR PUSTAKA}

Naskah Abdillah, L. 2020. Stigma Terhadap Orang Positif COVID-19 (Stigma on Positive People COVID-19). Pandemik
COVID- 19: Antara Persoalan Dan Refleksi Di Indonesia, Forthcoming. Arboleda, F. 2002. What causes stigma? World Psychiatry. https://www.ncbi.nlm.nih.gov/pmc/a rticles/PMC1489829/.a-Florez, 2002./

Arriandi, Christian. 2014. Persepsi Remaja Terhadap Sosialisasi Pacaran Sebagai Pendidikan Seks Oleh Crisis Center Cahaya Mentari Surabaya. Jurnal EKomunikasi, Vol 2 No. 1. 2014

Audita, M. 2020. Satgas: Stigma Negatif Bikin Pasien COVID-19 Menutup Diri, Hambat Tracing. Kumparan.Com. https://kumparan.com/kumparannew s/satgas-stigma-negatif-bikin-pasiencovid-19-menutup-diri-hambat- tracing1urw20HBhhL/full

Berger, P. 1994. Langit Suci Agama Sebagai Realitas Sosial. Jakarta: LP3ES.

Dianawanti, V. (2020). Riset Tunjukkan Gaya Hidup Orang Indonesia Berubah karena Virus Corona Covid-19. Liputan 6.

https://www.liputan6.com/bola/read /4225707/riset-tunjukkan-gaya- hiduporang-indonesia-berubah- karena-viruscorona-covid-19

Dong, Y., X, M., \& Hu, Y. 2020.

Epidemiology of Covid 19 Among Children in China. American Academy of Pediatrics, 145(6). https://doi.org/10.1542/peds.20200702

Handayani, D., Rendra Hadi, D., Isbaniah, F., Burhan, E., \& Agustin, H. 2020.

Penyakit Virus Corona 2019. Jurnal Respirologi Indonesia, 40, 14.

Hidayat, Andrea Gani. 2020. Impian Sebagai Ide Penciptaan Karya Seni Lukis. Institut Seni Indonesia Yogyakarta.

Hidayah, N., Sofia Rizki, A., Dwi Astutik, R., \& Eko Saputro, D. 2020. Analisis Terjadinya Anxiety Attack Pada Masyarakat Desa Selo Kecamatan

Tawangharjo Kabupaten Grobogan dalam Menghadapi Covid-19.

Indriyani, P., \& Yusuf, E. 2020. Konstruksi Makna Perempuan Pergerakan. 19(2), 238-248. 
Joharudin, A., Andi Septiandi, M., Maharani, S., Ditya Aisi, T., \& Nurwahyuningsih. 2020. Panic Syndrom Covid-19: Penekanan terhadap Kebijakan yang Diberikan Pemerintah. Jurnal Perpektif, 4 No. 1, 44-53.

Kesehatan RI, K. 2020. Pedomen Pencegahan dan Pengendalian Coronavirus Disease. https://covid19.go.id/p/protokol/ped oman-pencegahan-dan-pengendaliancoronavirus-disease-covid-19-revisi- ke5

Kuswarno, E. 2009. Fenomenologi: Metodologi Penelitian Komunikasi. Widya Padjadjaran.

L. Tubbs, S., \& Moss, S. 2006. Human Communication. Bandung: Remaja Rosda Karya.

Majid, A. 2000. Tantangan dan Harapan Umat Islam di Era Globalisasi.

Bandung: Pustaka Setia.

Muhasar. 2020. Pendidikan Agama Dalam Keluarga Menurut Nurcholish Madjid. Jurnal Pendidikan Islam, Vol 1, No 2, 2019.

Mulyana, D. 2010. Metode Penelitian Kualitatif: Paradigma Baru Ilmu Komunikasi dan Ilmu Sosial Lainnya. Bandung: Remaja Rosda Karya.

Neuman, W. L. 2015. Metodologi Penelitian Sosial: Pendeketan Kualitatif dan Kuantitatif. Jakarta: PT Indeks.

Novianti, N. 2017. Teaching Character Education to College Students Using Bildungsromans. International Journal of Instruction, 10, 255-272.

Perwira, B. 2019. Konstruksi Makna Perempuan Perokok. Tidak diterbitkan. Fakultas Ilmu Sosial dan Ilmu Politik, Universitas Singaperbangsa Karawang

Putri, Winda E. 2018. Pengalaman Komunikasi Mahasiswi Yang

Melakukan Hijrah. Jurnal JOM Fisip, vol 5: Edisi II Juli-Desember 2018.

Qomar, M. 2015. Dimensi Manajemen Pendidikan Islam. Jakarta: Erlangga.

Rahmadi, D. 2020. Stigma Negatif Bahayakan Pasien dan Penyintas Covid
19.

Merdeka.Com. https://www.merdeka.com/peristiwa

/stigma-negatif-bahayakan-pasien- danpenyintas-covid-19.html

Samani, M., \& Hariyanto. 2012. Konsep dan Model Pendidikan Karakter.

Bandung: Remaja Rosda Karya.

Setiawati, L., Sariti, I., \& Livana, P. 2020. Stigma dan Perilaku Masyarakat pada Pasien Positif covid-19. Jurnal Gawat Darurat, 2(2), 95-100.

Sobur, A. 2003. Psikologi Umum.

Bandung: Pustaka Setia.

Sobur, Alex. 2009. Semiotika Komunikasi.

Bandung: Pustaka Setia.

Sumiati. 2011. Mimpi sebagai Motivasi Berprestasi Meraih Cita-cita. Universiras Muhammadiyah Surakarta.

http://eprints.ums.ac.id/13889/ Tosepu, R., Gunawan, J., Effendy, D., Ahmad,

L., Lestari, H., \& Bahar, H. 2020. Correlation between weather and Covid-19 pandemic in Jakarta. Science of The Total Environment.

https://doi.org/10.1016/j.scitotenv.2 020.138436

Wiratama, Reyhan. 2018. Konstruksi Makna Fanatisme Bagi Squad Red Shield Pada Game Rising Force.

Bandung.

WHO. 2020a. Critical Preparedness Readliness and Response Actions for Covid $19 . \quad$ WHO. https://www.who.int/publications/i/i tem/critical-preparedness-readinessand-response-actions-for-covid-19

WHO. 2020b. Social Stigma associated with Covid 19: A guide to preventing and addressing. WHO. https://www.who.int/publications/m

/item/a-guide-to-preventing-andaddressing-social-stigma-associatedwith-covid-19

Wilsher, E. 2011. The impact of Neglected Tropical Disease, and their associated stigma, on people's basic capabilities. Durham University. http://etheses.dur.ac.uk/3301/1/THE SIS_FINALpdf.pdf. 
Wono, Hilda Y. 2019. Efektivitas Proses Komunikasi Interpersonal Antara Pembina Dengan Anak Asuhnya di Sanggar Merah Merdeka Surabaya. Jurnal Ilmu Komunikasi.

Yati Afiyanti, I. N. R. 2014. Metodologi penelitian kualitatif dalam riset keperawatan.

Yuliana. 2020. Corona Virus Disease (Covid 19) Sebuah Tinjauan Literatur. Wellness and Healthy Magazine. 